\title{
Contribution of RADARSAT-1 Images to Structural Geological Mapping and Lineament Density Assessment in the Lobo River Watershed at Nibéhibé (Centre-West, Côte d'Ivoire)
}

\author{
Souleymane Gningnéri Ouattara, Brou Dibi, and Jules Mangoua Oi Mangoua
}

\section{ABSTRACT}

\begin{abstract}
The populations living in the Lobo watershed at Nibéhibé are experiencing difficulties in obtaining drinking water. This situation is due to several factors, including a lack of control of the hydrogeological environment. The present study assesses the fracture network that has affected the Precambrian basement aquifer of the Lobo at Nibéhibé catchment area by structural mapping and by studying the spatial distribution of the lineaments. To do this, the study exploits the contribution of radar images. Manually and with the use of adaptive and median filters, 1330 lineaments of varying lengths were derived from the RADARSAT-1 image. The validation approach was based on the comparison of the lineament's orientations of the current study with those of previous studies, and on the position of the geophysically-implanted boreholes relative to the fractures. This approach showed that the lineaments would most often correspond to fractures and would be involved in the occurrence of groundwater. The analysis of the orientation distribution of the lineaments revealed the heterogeneity of the directions and the predominance of the N-S and E-W family directions. The lineament density map showed that the study area is intensely fractured with a proportion of $93 \%$. The results obtained from this thematic map are useful for the implementation of high efficiency hydraulic drilling programmes and for the implementation of water resources management tools.
\end{abstract}

Keywords: Lineament, RADARSAT-1, Lobo watershed at Nibéhibé, Precambrian basement aquifer.
Published Online: July 10, 2021

ISSN: $2684-446 \mathrm{X}$

DOI : 10.24018 /ejgeo.2021.2.4.147

\section{S. G. Ouattara*}

Department of Earth Sciences, Faculty of Geosciences and Environment, University of Jean Lorougnon Guédé of Daloa, Côte d'Ivoire.

(e-mail: ouattaragningneri@gmail.com) B. Dibi

Department of Earth Sciences, Faculty of Geosciences and Environment, University of Jean Lorougnon Guédé of Daloa, Côte d'Ivoire.

(e-mail: dibrou2003 @ yahoo.fr)

J. M. O. Mangoua

Department of Earth Sciences, Faculty of Geosciences and Environment, University of Jean Lorougnon Guédé of Daloa, Côte d'Ivoire.

(e-mail: mjul_2v@yahoo.fr)

*Corresponding Author

\section{INTRODUCTION}

If it is obvious that the fractured environment, and in particular the basement zones, are not devoid of water, it is also obvious that this water, because it is found in a discontinuous environment, is not distributed homogeneously, at least at the scale of the catchment. Indeed, a borehole, randomly implanted in a fractured aquifer, is unlikely to encounter, below the static level, enough interconnected open fractures for an exploitable flow. The study of fracturing is therefore the preliminary phase in the search for groundwater reservoirs. Studies [1]-[5] have shown that the fracturing field from satellite images brings out a lot of interesting information, especially because of its synoptic view and especially because of the various high quality digital image processing techniques. Remote sensing could therefore be a useful tool for studying fracture networks with a view to assessing water resources. Hydrogeological, geological, and structural knowledge is synthesised and processed using a Geographic Information System to help understand the behaviour of these fractured aquifers.

Radar remote sensing techniques seem to be the most suitable for tropical wetlands. Radar is not affected by atmospheric scattering. Due to their high sensitivity to surface features such as roughness and moisture, radar data are particularly effective for mapping linear structures corresponding to faults, fractures, and lithological contacts [6].

The geology of Côte d'Ivoire is $97.5 \%$ crystalline and crystallophyllous basement, so most of the water resources are contained in aquifers formed by the fractured basement, which is of considerable hydrogeological importance. The Lobo at Nibéhibé catchment area which is the subject of this study belongs to this domain. This region, which is favourable to agriculture (coffee, cocoa, rubber, and oil palm), attracts many people. However, population growth goes hand in hand with an increase in water requirements. With the worsening of constraints on surface water resources (reduced rainfall, eutrophication of reservoirs, severe low water levels, etc.), the population's drinking water supply is increasingly turning to the use of groundwater. 
The objective of this study is to evaluate the fracture network that has affected the Precambrian basement aquifer of the Lobo at Nibéhibé catchment area with a proposal to carry out structural mapping to study the spatial distribution of fractures. The information obtained can be used to guide future hydrogeological studies and contribute to the development of water resource management tools. The fracture network was mapped using a combination of RASARSAT-1 image data.

\section{MATERIALS AND METHODS}

\section{A. Study Area}

Geographically, the watershed of the Lobo River at Nibéhibé (Fig.1) is located in the central-western part of Côte d'Ivoire between $6^{\circ} 15^{\prime}$ and $6^{\circ} 55^{\prime}$ West longitude and between $6^{\circ} 45^{\prime}$ and $7^{\circ} 55^{\prime}$ North latitude with a surface area of about $7,000 \mathrm{~km}^{2}$. It has its source at an altitude of $400 \mathrm{~m}$ south of Séguéla [7]. The Baulean climate, characterised by two seasons, is observed throughout the basin. The seasons are divided into a rainy season (RS) from April to October with a slowdown in rainfall in July-August and a very marked dry season (DS) from November to March with some isolated rainfall. The average annual rainfall recorded over the period $1990-2015$ is $1,238.2 \mathrm{~mm}$. The average monthly temperature trend varies between $24^{\circ} \mathrm{C}$ and $28^{\circ} \mathrm{C}$, with a temperature range of $4{ }^{\circ} \mathrm{C}$.

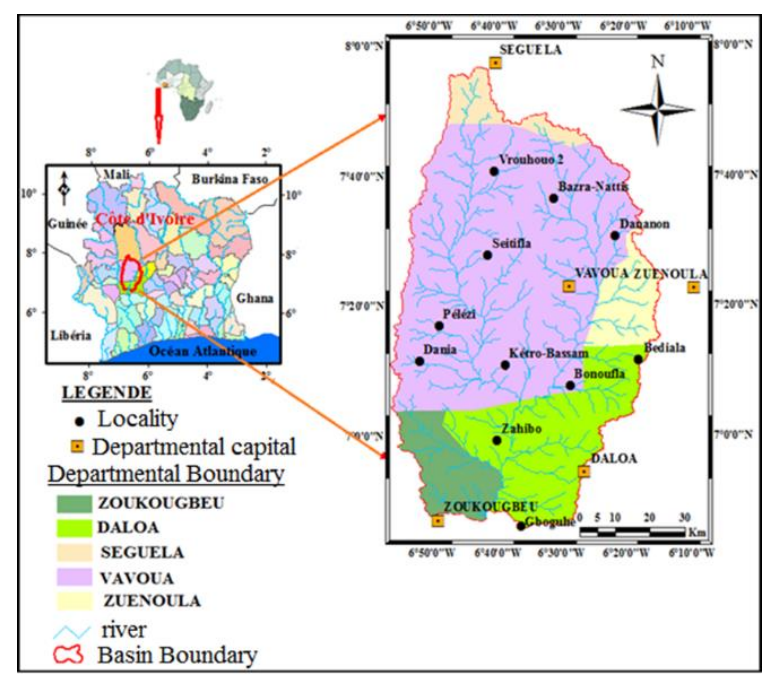

Fig. 1. Geographical location of the Lobo watershed at Nibéhibé.

The geological formations of the Lobo catchment area belong mainly to the Precambrian basement (Middle Precambrian) and are grouped into two main entities: magmatic rocks and metamorphic rocks (Fig. 2). The geology of the basin is known from the work of [9], [10]. The magmatic rocks encountered are of plutonic and volcanic types. They are mainly represented by granitoids, which are found in most of the basin. The composition of these rocks varies from granite to granodiorites. These formations occur in the form of small elongated masses in the Eburnian direction. The metamorphic rocks in the basin are schistose. The schistous ensemble of the basin is characterized by a zonation in the arrangement of the facies. In the north, the schists have a longitudinal band of metasiltites dominating over meta-arenites. In the extreme north-west, there is an intrusion of greenstone. This rock constitutes amphibolitic schists derived from various basic rocks (dolerites and gabbros) [11], [12].

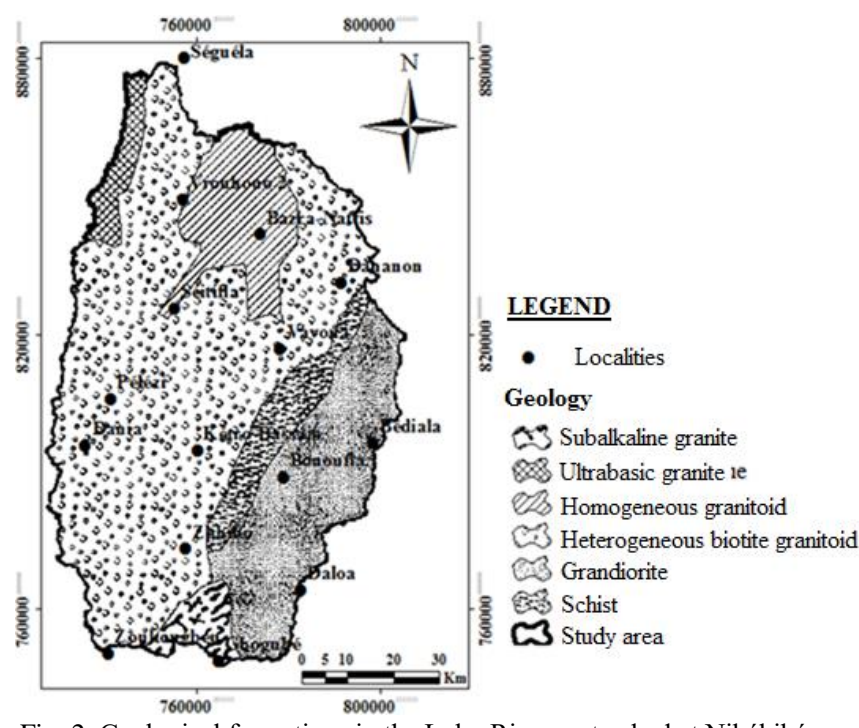

Fig. 2. Geological formations in the Lobo River watershed at Nibéhibé [11]-[12]

Hydrogeologically, there are generally two types of aquifers: alterite aquifers (superficial) and fractured aquifers (deeper). Alterites are the first level of groundwater reservoir in crystalline and crystalline basement environments. They are surface formations resulting from physical-chemical weathering and erosion processes of the basement. These alteration aquifers develop in sandy-clay formations and in granitic arenas. Fissure aquifers, which underlie the weathering aquifers, are much more important reservoirs. These aquifers generally arise as a result of tectonic events that affect the upper and middle levels of the Earth's crust [13]. They extend on average over a thickness of $50 \mathrm{~m}$ [14] in the basement and develop a higher productivity than the alterites.

\section{B. Cartographic Data, Satellite Data and Computer Equipment}

During this study, two geological maps and a photogeological map were used. These are the geological maps at 1:200,000 for the localities of Daloa and Séguéla [11]-[12] and the photogeological map of the study area [15] at 1:500,000. The 1:200,000 scale geological maps are provided by the mining development company.

The images used are essentially RADARSAT- 1 with a spatial resolution of $30 \mathrm{~m}$. The radar images used are composed of two scenes, including scenes 184-308 and 184333 of 11 February 2018 acquired in the dry season, covering the entire Lobo at Nibéhibé watershed. These two scenes were mosaicked to have a single radar image.

The processing and exploitation of the RADARSAT-1 image was carried out using SNAP 7.0 software, which includes multiple functionalities for image processing and thematic mapping. ArcGis 10.4.1 software was used for lineaments extraction and automatic lineaments counting. Linwin 2.2 software was used to pre-process the fracture map in order to calculate the parameters (fracture lengths and fracture density) required for statistical analysis and to produce the directional rosettes. 


\section{Methodology}

The flowchart in Fig. 3 presents the methodology of radar image processing for the production of lineament maps. The lineament mapping is based on the RADARSAT-1 image. The image is processed with adaptive filters to reduce noise and with median filters. The structural lineaments are extracted from the noise-free images, taking care to exclude those of anthropogenic origin. After all structural lineaments have been extracted, they are subjected to a validation procedure.

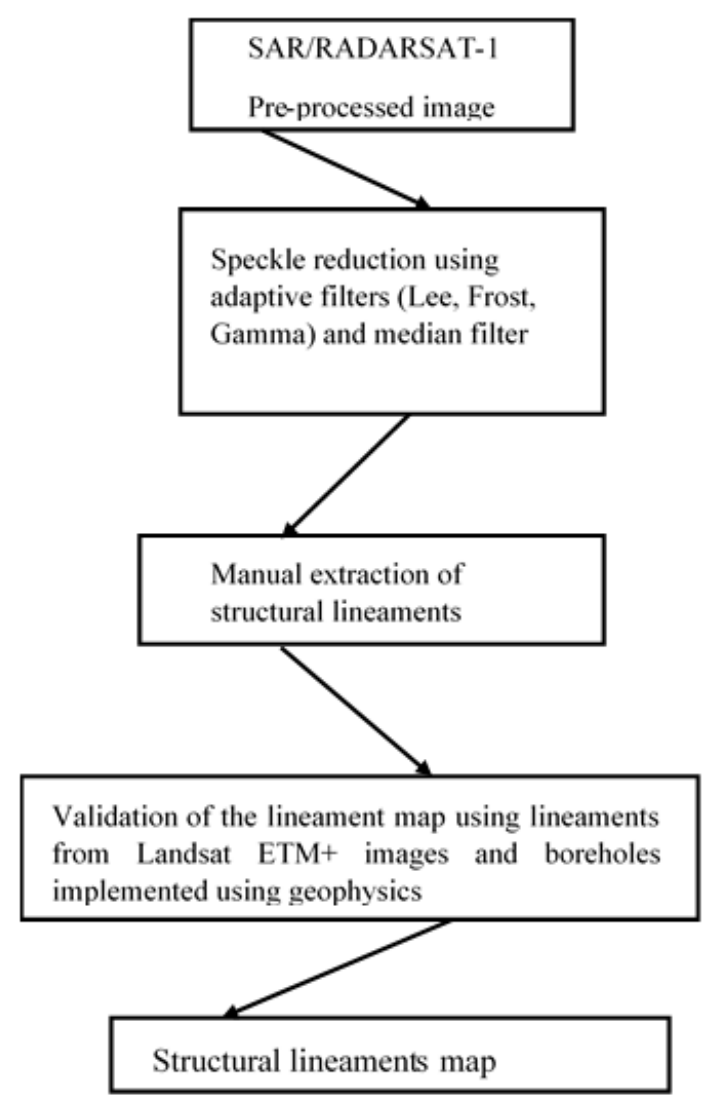

Fig. 3. Radar image processing methodology for the production of lineaments maps.

Any non-useful data that masks the desired information must be eliminated. For those acquired by active microwave, most of the noise comes from the speckle effect. This reduces the possibility of discriminating between structures, especially the finest ones. In order to mitigate this effect, adaptive filters from Lee [16], Frost [17] and Gamma [18] as well as the median filter [19] were used for noise processing. These filters maintain the sharpness and detail of the image while stopping the noise. Statistical and visual results showed that the median filter, with a window size of 5x5, was most suitable for our standard mode radar image. The lineament extraction was therefore performed after applying the median filter.

Lineaments were extracted manually from filtered images after visual analysis on screen. in fact, linear anthropogenic discontinuities such as roads, paths and industrial plantation boundaries are digitized from images in an existing database and from Google Earth 2020 images. as these human-related features are quite dynamic, it is wise to derive them from images with recent acquisition dates, compared to the images used for structural mapping. Subsequently, the vector file of the anthropogenic lineaments is alternately overlaid and removed from the radar image, when extracting the structural lineaments. The geological structure map is obtained from a synthesis of the lineament mapping details.

The validation of the lineaments found following the various treatments that have preceded consists of bringing the lineaments mapped in our work into conformity with those of previous works [16], [10]. In our study, the validation consisted in comparing and highlighting the possible correspondences between the directions of the major fractures extracted from the lineament map and those of the previous works of the ETM+ Landsat 7 images [7] and of the drilling rates carried out in the area using geophysics. The aim is to report the structural matches and contours of the different lithological formations observed. The correspondence of the observed features to those previously identified takes into account the nature of the structures, the size and their orientation.

The lineament map is georeferenced for recognition by the Linwin 2.2 statistical software. This establishes both the directional rosette of the lineaments and the number and cumulative length of the lineaments. The orientations of the lineaments are given by the directional rosette (represented by circular histograms) and are divided into 10 degree classes. The statistical processing of the lineament field aims to construct the lineament density map. The approach adopted here is the discretization of the lineament field into meshes by considering the Representative Elemental Area (REA) of the lineaments. The dimensions of the latter for which the directional distribution of the lineaments is coherent in the lineament field are $5 \times 5 \mathrm{~km}$ in regular mesh. This surface was used to carry out the study because it allows a good refinement of the mesh of the rectangular zone delimiting the lineaments. In each mesh, the total number of lineaments and the length of each lineament are determined. The interest of this map is to highlight the spatial variability of the fracturing intensity at small scale of investigation. Interpolation using the IDW method was carried out to produce the iso value map of the cumulative length density or number of major lineaments. The so-called major lineaments are lineaments of regional extension. In this study, lineaments longer than $9 \mathrm{~km}$ are referred to as major lineaments, following the work of [20] and [21].

\section{RESULTS}

\section{A. Lineament Map}

The use of filtered RADARSAT-1 images led to different results. These images allowed to identify several lineaments with lengths ranging from 0.08 to $82 \mathrm{~km}$ (Fig. 4). These lineaments are represented by two maps: the detailed lineament map (Fig. 4a) and the major lineament map (Fig. 4b). The detailed lineament map consists of 1330 lineaments and the major lineament map (with lengths greater than 9 $\mathrm{km})$. The distribution of these major lineaments is not homogeneous from the study area. 


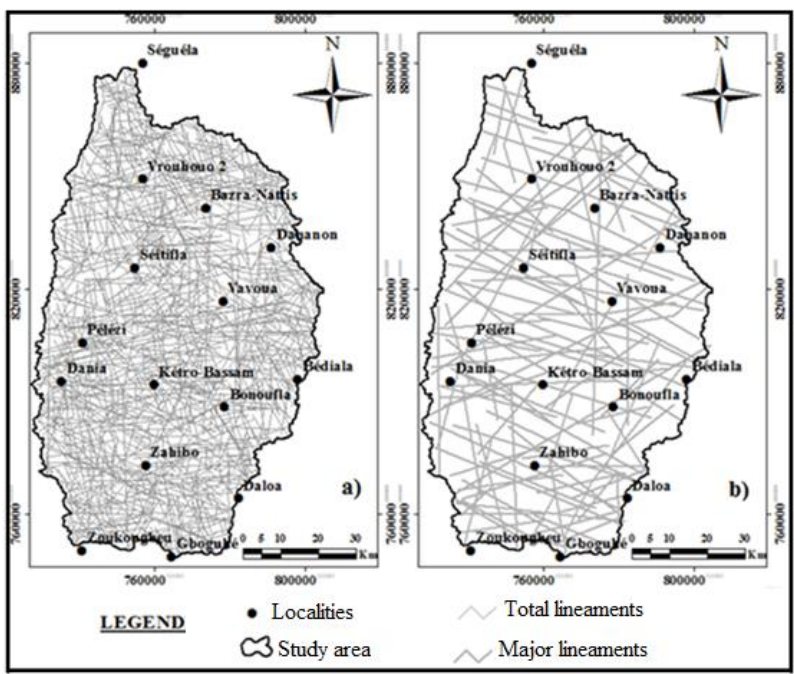

Fig. 4. Lineament map of the Lobo at Nibéhibé watershed; a): Total lineaments; b): Major lineaments; c): Directional rosettes.

\section{B. Distribution of Orientations in Number and Cumulative Length of Lineaments}

The distribution of orientations in number and cumulative length of lineaments is represented by the directional rosette which shows various proportions (Fig. 5). The directional rosette (Fig. 5a) with an interval of $10^{\circ}$ associated with the detailed lineament network reveals two major orientations N0-10 (14\%) and N90-100 (12\%) which correspond to the N$\mathrm{S}$ and E-W directions respectively. Secondary orientations are the classes N70-80 (7\%), N100-110 (7\%), N150-160 $(7 \%)$. In the region, we also note the presence of lineaments of orientation $\mathrm{N} 60-70, \mathrm{~N} \mathrm{110-120}$ and $\mathrm{N} \mathrm{160-170.} \mathrm{They}$ present frequencies in number and in cumulative length of $6 \%$, they are in the minority. As for the directional rosette of the major fractures (Fig. 5b), it also has two major orientations, N0-10 (11\%) and N110-120 (14\%), which correspond to the N-S and NW-SE directions respectively. This network of lineaments indicates a channelization of the groundwater flows along the different orientations. These groundwater flows are for the most part imposed by the large fracture corridors, depending on whether they are open or semi-open.

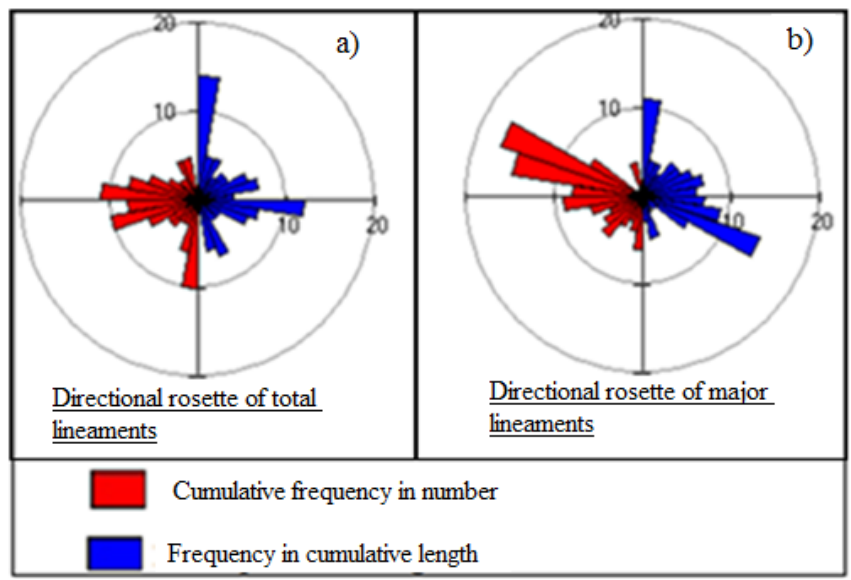

Fig. 5. Directional roses of lineament maps; a) Directional rose of detailed lineaments, b) Directional rose of major lineaments.

\section{Validation of Lineaments}

From Fig. 6, the major lineaments are compared to the geological structures from previous work using Landsat 7/ETM+ images [7]. This approach allowed the lineaments of the Lobo catchment to be validated with respect to their size and orientation. In the study area, the fractures in the Landsat 7 ETM+ image are 59 in number, thus less representative. However, a perfect match of 25 existing fractures out of a total of 59 is established with those of the major lineaments of the Lobo at Nibéhibé watershed from the RADARSAT-1 images.

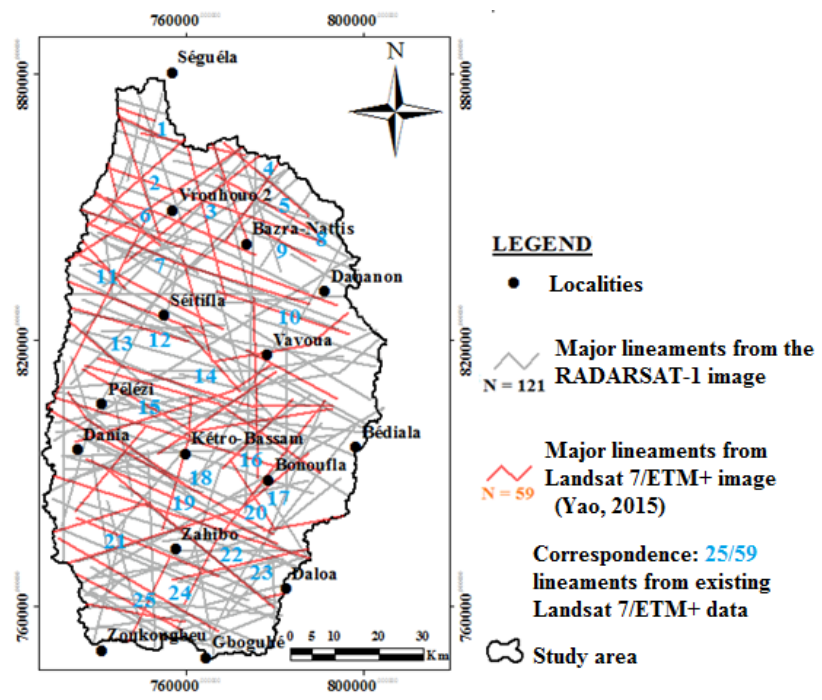

Fig. 6. Validation of the major lineaments of the Lobo watershed at Nibéhibé from Landsat 7/ETM+ data using major lineaments.

In addition to validating the major faults with the fractures in the ETM+ Landsat 7 image, we used the boreholes drilled with geophysics in the study area. These boreholes were superimposed on the map of major lineaments from the RADARSAT-1 image (Fig. 7). Indeed, it can be seen that these boreholes are aligned or close to most of the mapped lineaments, even if the flow rate of some of these boreholes is low $\left(<2 \mathrm{~m}^{3} / \mathrm{h}\right)$. This result shows that the most important flow rates obtained in this region would be linked to the major lineaments.

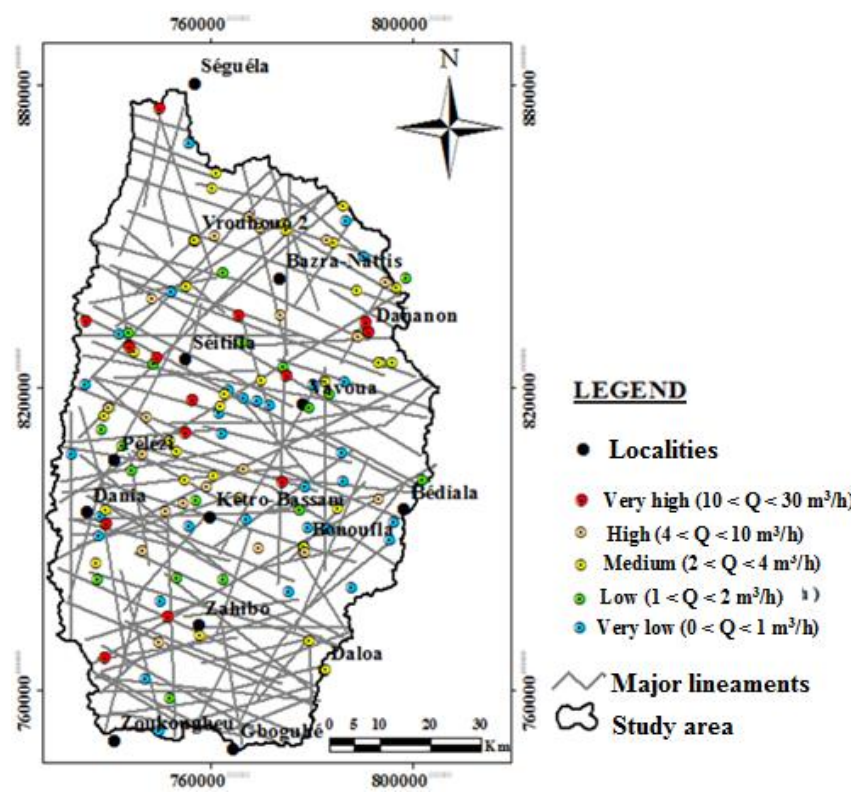

Fig. 7. Superposition of boreholes drilled using geophysics and major lineaments.

\section{Density Map of the Lineaments}

The statistical analysis of the major lineaments of the Lobo at Nibéhibé catchment area has resulted in the lineament 
density map (Fig. 8). The analysis of this map shows a density that highlights 4 classes including Low, Medium, High and Very high. The low density zones occupy about $7 \%$ of the total surface area of the study area and are found exclusively at the extremities of the basin, with a few islands in the north, northwest and southeast. As for the medium density class, it represents $31 \%$ of the total surface area of the investigation area. This class is more present in the north, east, west and south, with a few isolated pockets in the central part. The high density class is the most important class in the study area. It covers an area of $35 \%$ and is reported in all sectors of the study area. This class is more pronounced in the south and in the central part of the basin. The very high density class, which covers $27 \%$ of the study area, is also found in almost the entire study area. This class is more pronounced in the northwest and south. The high and very high density sectors are considered to be areas that are highly susceptible to seepage.

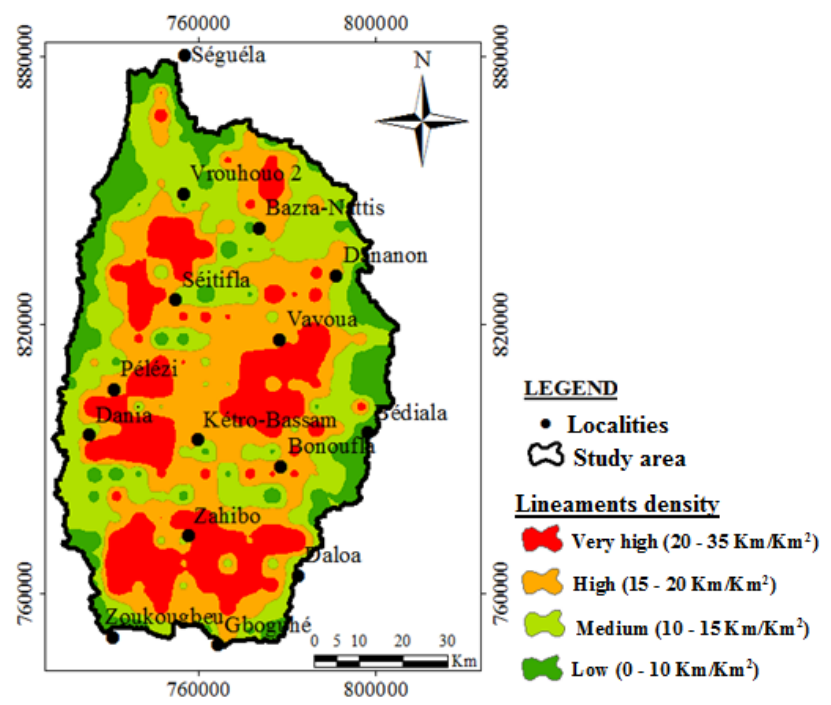

Fig. 8. Lineament density map of the Lobo at Nibéhibé watershed.

\section{DISCUSSION}

The major lineaments found in this study from RADARSAT-1 images number 121. These appear high compared to those obtained by [7] from ETM+ Landsat 7 images over the same study area. This provides good information on the use of remote sensing methods for lineament mapping. Indeed, lineament mapping has various limitations, one of the limitations highlighted by [22] is that the result of this lineament mapping is highly dependent on the experience of the image photo-interpreter. [23] state that the processing of satellite images is regularly confronted with the problem of the reliability of the results obtained and the problem of the validation of these results. Obtaining elements for the validation of lineaments is quite complex. Not all rocks are exposed and even if there are outcrops, not all lineaments are visible and access to the outcropping area is not always obvious [24]. Another limitation of using satellite images for lineament mapping is related to the spatial resolution of these images. The RADARSAT-1 images used have a resolution of $30 \mathrm{~m}$. Therefore, only structures with lengths greater than the $30 \mathrm{~m}$ spatial resolution are mapped. Despite these limitations, the use of remote sensing has led to enormous successes in terms of access to safe drinking water.
Furthermore, the study of the orientation distributions of the lineaments showed directional heterogeneity. Two main families of orientation appeared (N-S and E-W). Several works carried out in other localities in Côte d'Ivoire, including [25] in Sinfra, [26] in Dimbokro, [27] and [28] in Soubré have also identified these directions. The work of [29] in the Rifian inner domain in Morocco and [30] in Tunisia have identified these same directions. On the other hand, in the study area, the two major orientation families obtained by the previous works of [15] and [7] respectively using aerial photography and ETM+ Landsat 7 images are the NE - SW and NW - SE directions. 7 and 59 major lineaments were identified respectively by the works of [15] and [7] contrary to the RADARSAT-1 image whose number of identified major lineaments is 127 . This difference in the main directions and the number of major lineaments is linked to several factors. Indeed, in RADARSAT-1 images such as those studied, the textural properties of the imaged scene as well as the useful spatial resolution of the RADARSAT-1 sensor are better preserved. In addition, not only does the radar image enhance the lineaments perpendicular to the direction of illumination of the radar wave, but also those parallel to this direction are almost enhanced. These radar images address some challenges such as the observation made by [15] who stated that the N80-100 (E-W) direction is not too visible in satellite imagery. The fracture density map shows that the Lobo at Nibéhibé catchment is highly fractured with the medium, strong, and very strong fracture classes represented by $93 \%$. These results are almost identical to those obtained by [7] which is $90 \%$. Using the assumption that lineaments correspond to brittle structures in the bedrock, the intersection provides important information. A higher intersection of lineaments and higher density therefore indicates places where groundwater could flow more [31].

\section{CONCLUSION}

This study was carried out to map and analyse the spatial distribution of fractures in the Precambrian basement of the Lobo watershed at Nibéhibé, in the forest zone of westcentral Côte d'Ivoire. To this end, the contribution of radar images, relatively more adapted to this constantly cloudy area, was exploited for the extraction of lineaments. After using the adaptive and median filters (without using directional filters) and by visual analysis on screen, 1330 total lineaments were extracted from the RADARSAT-1 images manually. From these total lineaments, 121 major lineaments were extracted and used for lineament density mapping. The validation approach revealed that the lineaments mostly correspond to fractures and are involved in groundwater occurrence. The analysis of the orientation distribution revealed a directional heterogeneity in which the N-S and E$\mathrm{W}$ orientation families are mainly observed. The lineament density map shows that the area is intensely fractured with a proportion of $93 \%$. 


\section{REFERENCES}

[1] J.C. Maréchal, B. Dewandel, K. Subrahmanyam, "Use of hydraulic tests at different scales to characterize fracture network properties in the weathered-fractured layer of a hard rock aquifer," Water resources Research, vol. 40, no. 11, pp. 1-17, 2004.

[2] I. Galanos, D. Rokos, "A statistical approach in investigating the hydrogeological significance of remotely sensed lineaments in the crystalline mountainous terrain of the island of Naxos, Greece," Hydrogeology Journal, vol. 14, pp. 1569-1581, 2006.

[3] P. H. Giao, A. Weller, D. H. Hien, K. Adisornsupawat, "An approach to construct the weathering profil in hilly granitic terrain based on electrical imaging," Journal of Applied Geophysics, vol. 65, pp. 30-38, 2008.

[4] M. Youan Ta, T. Lasm, J.P. Jourda, K.F. Kouame, M. Razack, "Cartographie structurale par imagerie satellitaire ETM+ de Landsat-7 et analyse des réseaux de fractures du socle précambrien de la région de Bondoukou (Nord-Est de la Côte d'Ivoire)," Revue Télédétection, vol. 8, no. 2, pp. 119-135, 2008.

[5] Y.A. N'go, T. Lasm, M. Koita, I. Savane, "Extraction par télédétection des réseaux de fractures majeures du socle précambrien de la région de Dimbokro (Centre-est de la Côte d'Ivoire)," Revue Télédétection, vol. 9, no. 1, pp. 33-42, 2010.

[6] S. Wade, A. Ndoye, M. Mbaye, "Fusion d'images optique et radar : application à la cartographie du massif granitique de Bambadji (Falémé, Sénégal oriental)," Télédétection, vol. 2, no. 2, pp. 119-127, 2001.

[7] A.B. Yao, "Evaluation des potentialités en eau du bassin versant de la Lobo en vue d'une gestion rationnelle (Centre-ouest de la Côte d'Ivoire)," Thèse De Doctorat, Département de sciences naturelles, Université Nanguy Abrogoua, Abidjan, Côte d'Ivoire, 2015.

[8] G.S. Ouattara, B. Dibi, B.A. Konan-Waidhet, O.M.J. Mangoua, B. Kamagaté, "Study of Groundwater-river Interactions Using Hydrochemical Tracers in Fissured Rock: Case of the Lobo Watershed at Nibéhibé (Central-West, Côte d'Ivoire)," International Journal of Environment and Climate Change, vol. 10, pp. 55-66, 2020.

[9] O.A. Ahimon, "Notice explicative de la carte géologique à 1/200 000, feuille de Daloa," Direction de la géologie, Abidjan, p. 28, 1990.

[10] C. Delor, Y. Simeon, M. Vidal, Z. Zeade, Y. Kone, M. Adou et al, "Carte géologique de la Côte d'Ivoire à 1/200 000, feuille Séguéla," Mémoire $\mathrm{n}^{\circ} 9$ de la Direction des Mines et de la Géologie, Abidjan, p. $19,1995$.

[11] B. Tagini, "Esquisse structurale de la Côte d'Ivoire. Essai de géotectonique régionale," Thèse de Doctorat 3ème cycle, Université de Lausanne, Suisse, Bulletin SODEMI, (5), 1971.

[12] K.K. Pothin, "Pétrographie et géochimie des formations précambriennes de la région d'Odienné (Nord-Ouest). Typologie du volcanisme birimien. Tendances évolutives du Magnétisme Eburnéen. Géochimie de l'Uranium et du Thorium dans les granitoïdes," Thèse de Doctorat d'Etat ès-Sciences Naturelles, Université Nationale de Côte d'Ivoire, Abidjan, Côte d'Ivoire, 1988.

[13] A.N. Sawadogo, "Géologie et hydrogéologie du socle cristallin de la Haute Volta : étude régionale du bassin versant de lma Sissili," Thèse de Doctorat d'Etat, Université de Grenoble, Grenoble, France, 1984.

[14] J.C. Maréchal, W. Robert, L. Patrick, S. Kambhampati, T. Frédéric, "Anisotropie verticale de la perméabilité de l'horizon fissuré des aquifères de socles : concordance avec la structure géologique des profils d'altération," Comptes Rendus Géosciences, vol. 335, pp. 451460, 2003.

[15] J. Biemi, “Contribution à l'étude géologique, hydrogéologique et par télédétection des bassins versants subsahéliens du socle précambrien d'Afrique de l'Ouest : Hydrostructurale, Hydrodynamique, Hydrochimie et Isotopie des aquifères discontinus de sillons et aires granitiques de la haute Marahoué (Côte d'Ivoire)," Thèse de Doctorat d'Etat, Université d'Abidjan, Abidjan, Côte d'Ivoire, 1992.

[16] J.S. Lee, K.w. Hoppel, S.A. Mango, A. Miller, "Intensity and phase statistics of multiloock polarimetric interferometric SAR imagery," IEEE Trans. Geosci. Remote Sens. Vol. 32, pp. 1017-1028, 1994.

[17] V.S. Frost, J.A. Stiles, A. Josephine, K.S. Shanmugan, J.C Holtzman, "A model for radar images and its application to adaptive digital filtering of multiplicative noise," IEEE Trans. Pattern Anal. Machine Intell. Vol. 4, pp. 157-166, 1982.
[18] A. Lopes, R. Touzi, E. Nezry, "Adaptative speckle filters and scenes heterogeneity," IEEE Trans. Geosci. Remote Sens, vol. 28, no. 6, pp. 992-1000, 1990.

[19] S. Haralick, Zhuang, "Image analysis using mathematical morphology," IEEE Trans. Pattern Anal. Machine Intell. Vol. 9, no. 4, pp. 532-550, 1987.

[20] D. Baka, "Géométrie, hydrodynamisme et modélisation des réservoirs fracturés du socle protérozoïque de la région d'Oumé (Centre-Ouest de la Cote d'Ivoire)," Thèse Unique, Univ. F.H. Boigny, Abidjan, Côte d'Ivoire, 2012.

[21] K.T. Yao, M.-S. Oga, K.E. Kouadio, O. Fouché, G. Ferriere, C. Pernelle, "Rôle hydrogéologique des linéaments structuraux en milieu cristallin et cristallophyllien : cas du bassin versant du Sassandra, SudOuest de la Côte d'Ivoire," Afrique Sci. Vol. 10, no. 4, pp. 78-92, 2014.

[22] P. Sander, "Lineaments in groundwater exploration: a review of applications and limitations," Hydrogeol. J, vol. 15, pp. 71-74, 2007.

[23] J. Fontès, P. Estève, Gastellu J.-P. Chegorry, "Validation des résultats de traitements d'images spatiales appliqués à l'étude de la dégradation des écosystèmes ligneux secs du Burkina Faso. La réalité de terrain en télédétection : pratiques et méthodes," Edition AUPELF-UREF, pp. 135-143, 1998.

[24] B.O. Tagnon, V.T. Assoma, J.M.O. Mangoua et al., "Contribution of SAR/RADARSAT-1 and ASAR/ENVISAT images to geological structural mapping and assessment of lineaments density in DivoOume area (Côte d'Ivoire)," The Egyptian Journal of Remote Sensing and Space Sciences, https://doi.org/10.1016/j.ejrs.2018.12.001, 2018.

[25] V.H. N'Guessan Bi, M.B. Saley, S. Wade, E.V. Djagoua, F. Kouamé, K. Affian "Extraction par télédétection et analyse statistique du réseau de fractures, en milieu de socle, dans le département de Sinfra (CentreOuest de la Côte d'Ivoire)," International Journal of Innovation and Scientific Research, vol. 13, no. 1, pp. 225-238, Janvier 2015.

[26] A.Y. N'go, T. Lasm, M. Koita, I. Savané, “Extraction par télédétection des réseaux de fractures majeures du socle précambrien de la région de Dimbokro (centre est de la Côte d'Ivoire)," Revue Télédétection, vol 9, no 1, pp. 33-42, 2010.

[27] M.V. Sorokoby, M.B. Saley, F.K. Kouamé, E.V Djagoua, M. Bernier, K. Affian, J. Biémi, "Utilisation des images Landsat ETM+ et du SIRS pour la cartographie linéamentaire et thématique de Soubre-Meagui," Revue Télédétection, vol. 9, no 3-4, pp. 209-223, 2011.

[28] T.K. Yao, O. Fouché-Grobla, S. Oga.,V. Assoma, "Extraction de linéaments structuraux à partir d'images satellitaires, et estimation des biais induits, en milieu de socle précambrien métamorphisé," Revue Télédétection, vol. 10, no 4, pp. 161-178, 2012.

[29] L.A. Brahim, F.S Alaoui, "Utilisation de la télédétection pour l'analyse de la fracturation du domaine Interne rifain (Maroc)," : relation avec la Répartition des sources, Télédétection, vol. 3, n 1, pp. 33-47, 2003.

[30] I. Ezzine, F. Zargouni, M. Ghanmi, “Analyse linéamentaire des images Landsat-TM et spot de l'atlascentro-septentrional : cartographie du prolongement SW de la cicatrice de Zaghouan," Revue Télédétection, vol. 10, no 4, pp. 199-211, 2012.

[31] G.T. Lalèyê, E.W. Vissin, C.S. Houssou, P. Edorh, Relation eau de ruissellement et eau des sources et forages artésiens dans la région Zagnanado-Zogbodomey au Bénin : Approche couplée (pollution microbiologique - télédétection)," International. Journal of Biological and Chemical Sciences, vol. 8, no. 6, pp. 2786-2803, 2014.

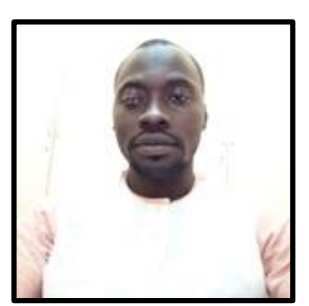

Ouattara. G. Souleymane holds a master's degree in water and environmental engineering obtained in 2017 from the Department of Earth Sciences of the Faculty of Geosciences and Environment of the Jean Lorougnon Guédé University in Daloa, Côte d'Ivoire. The master's degree consisted in assessing the impact of mining operations on the quality of underground resources of the Angovia gold mine located in central Côte d'Ivoire.

Since 2018, he is enrolled in a PhD program and is currently in his third thesis. His thesis focuses on the study of groundwater-river interactions in the Lobo watershed at Nibéhibé.

Mr Ouattara is the author of a scientific paper on the study of groundwater-river interactions. 